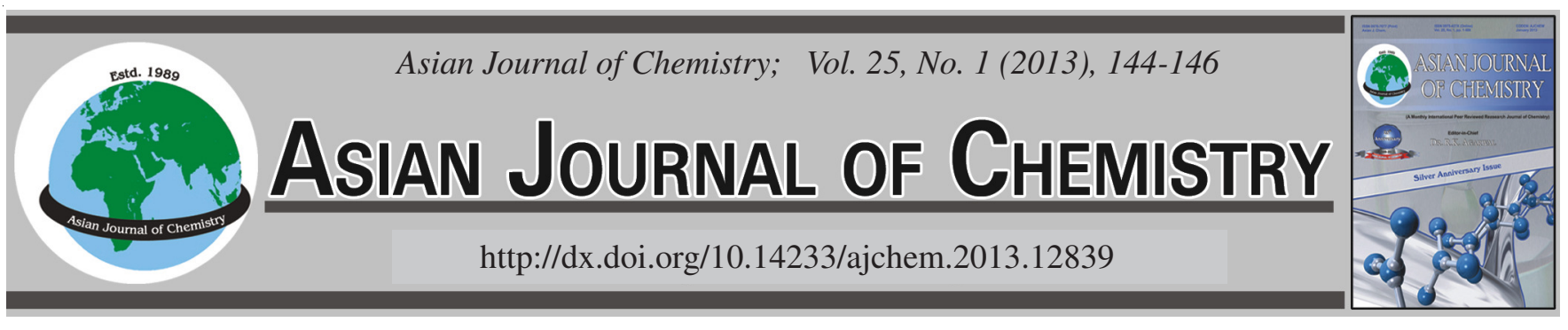

\title{
Simplified Cloud Point Extraction-Flame Atomic Absorption Spectrometry for the Preconcentration/Analysis of Trace Palladium
}

\author{
Ou Sha ${ }^{1,2, *}$ Yin LiaO ${ }^{1}$, Yun ZhOU ${ }^{1}$ and Weixing MA ${ }^{1}$
}

${ }^{1}$ School of Chemistry and Chemical Engineering, Huaihai Institute of Technology, Lianyungang 222005, P.R. China

${ }^{2}$ Department of Chemistry of Yangzhou University, Yangzhou 225002, P.R. China

*Corresponding author: Tel: +86518 85895063, E-mail: 7993259@163.com

(Received: 11 October 2011;

Accepted: 12 July 2012)

AJC-11836

\begin{abstract}
In this paper, a new simplified cloud point extraction for trace palladium as a prior step to its determination by flame atomic absorption spectrometry has been developed. The separation of $\mathrm{Pd}(\mathrm{II})$ by cloud point extraction involves prior formation of a complex $\left[\mathrm{PdCl}_{4}\right]^{2-}$ with sufficient KI to be extracted into the small volume of the Triton X-100-rich phase and yield the desired preconcentration. This procedure does not need any organic chelating agent as well as long incubation time. The parameters of extraction system were investigated in detail. At optimum conditions, the linear range of $\mathrm{Pd}(\mathrm{II})$ was $0.1-60.0 \mu \mathrm{g} \mathrm{mL} \mathrm{m}^{-1}$. The correlation coefficient and the limit of detection were 0.9962 and $0.086 \mu \mathrm{g} \mathrm{mL}^{-1}$ respectively. The proposed method was applied to extract trace amounts of Pd(II) in synthetic sample and palladium catalyst waste water with satisfactory results.
\end{abstract}

Key Words: Palladium, Cloud point extraction, Flame atomic absorption spectrometry.

\section{INTRODUCTION}

Palladium is used as a precious metal in jewellery and in some forms of chemical apparatus. It is also an excellent conductor of electricity and used for electrical contacts and in catalytic converters. But the concentration of palladium in environmental, geological and metallurgical materials is usually too low to be directly determined owing to insufficient sensitivity and matrix interferences ${ }^{1,2}$. Therefore, the application of highly sensitive techniques, ICP-AES ${ }^{3,4}$, ICP-MS ${ }^{5,6}$, GF $\mathrm{AAS}^{7,8}$, coupled with a separation and enrichment procedure is necessary ${ }^{9-14}$.

In this paper, a new simplified cloud point extraction for trace palladium as a prior step to its determination by flame atomic absorption spectrometry has been developed. It was based on the cloud point extraction of $\left[\mathrm{PdCl}_{4}\right]^{2-}$ (which formed from the reaction between $\mathrm{Pd}(\mathrm{II})$ and KI by Triton X-100 as a surfactant. The proposed method was applied to extract trace amounts of Pd(II) in synthetic sample and palladium catalyst waste water with satisfactory results.

\section{EXPERIMENTAL}

A ZEEnit 700 (Analytik Jena, Germany) atomic absorption spectrometer, a MT-31 YAMATO Touch mixer(Yamato Scientific Co., Ltd) and pHs-25 pH meter (Shanghai Precision and Scientific Instrument) were used.
A stock standard solution of $\mathrm{Pd}(\mathrm{II})$ at a concentration of $1000 \mu \mathrm{g} \mathrm{mL} \mathrm{m}^{-1}$ was used. Working standard solutions were obtained by appropriate dilution of the stock standard solution. A solution of $10 \%(\mathrm{~m} / \mathrm{v})$ of Triton X-100 was obtained by dissolving $10 \mathrm{~g}$ Triton $\mathrm{X}-100$ in water and diluting to $100 \mathrm{~mL}$ in a volumetric flask. $0.2 \mathrm{~mol} \mathrm{~L}^{-1} \mathrm{KI}$ solution and $\mathrm{NaCl}$ were used.

Britton-Robinson buffer solutions (B-R) were prepared by mixing the mixed acid (composed of $0.04 \mathrm{~mol} \mathrm{~L}^{-1} \mathrm{H}_{3} \mathrm{PO}_{4}$, AcOH and $\mathrm{H}_{3} \mathrm{BO}_{3}$ ) with $0.2 \mathrm{~mol} \mathrm{~L}^{-1} \mathrm{NaOH}$ in proportion. The buffer solutions were prepared to adjust the acidity of the system.

All reagents used were of analytical reagent grade and the solutions were prepared with distilled water unless otherwise specified.

\section{Procedure}

A solution containing Pd(II) was transferred to a $5 \mathrm{~mL}$ centrifuge tube with a graduation line. After adding $1 \mathrm{~mL} \mathrm{pH}$ 6.0 BR buffer solution, $0.50 \mathrm{~mL} 0.2 \mathrm{~mol} \mathrm{~L}^{-1} \mathrm{KI}$ solution and $1 \mathrm{~mL} 10 \%$ Triton $\mathrm{X}-114$ solution, the solution was diluted to $5.0 \mathrm{~mL}$ with distilled water. Then $1 \mathrm{~g} \mathrm{NaCl}$ was added to this solution, then shake evenly. The resultant solution immediately turned turbid at $50{ }^{\circ} \mathrm{C}$ temperature for $20 \mathrm{~min}$. Phase separation was accelerated by centrifuging the tubes at 4000 rpm for $10 \mathrm{~min}$. The aqueous phase was then separated by a syringe without cooling in an ice bath. After adding $1 \mathrm{~mL}$ pH 6.0 BR buffer solution, the surfactant-rich phase of this 
procedure was diluted to $2 \mathrm{~mL}$ and was determined by flame atomic absorption spectrometry against a blank solution. The extraction efficiency of $\mathrm{Pd}(\mathrm{II})$ is the ratios of the amount of the solution after cloud point extraction to the one of the origin solution.

\section{RESULTS AND DISCUSSION}

Effect of salts on cloud point extraction efficiency: The effects of different salts on cloud point temperature and extraction efficiency of $\mathrm{Pd}(\mathrm{II})(\mathrm{E} \%)$ were studied. It was found that there is little effect of $\mathrm{Na}_{2} \mathrm{SO}_{4}, \mathrm{NaCl}, \mathrm{NH}_{4} \mathrm{Cl}$ on $\mathrm{E} \%$, but $\mathrm{E} \%$ was dramatically reduced with the increase of the concentrations of $\mathrm{CH}_{3} \mathrm{COONH}_{4}$ and $\mathrm{Na}_{2} \mathrm{CO}_{3}$, the reasons could be that $\mathrm{CH}_{3} \mathrm{COONH}_{4}$ affected the process of phase separation and the $\mathrm{pH}$ of the system was altered by $\mathrm{Na}_{2} \mathrm{CO}_{3}$. To sum up, $\mathrm{NaCl}$ was chosen as the additive.

Effect of $\mathbf{p H}$ on extraction efficiency: Cloud point extraction of $\mathrm{Pd}(\mathrm{II})$ were performed in different $\mathrm{pH}$ buffer solutions. The separation of $\mathrm{Pd}(\mathrm{II})$ by cloud point extraction involves prior formation of a complex $\left[\mathrm{PdCl}_{4}\right]^{2-}$ with sufficient $\mathrm{KI}$ to be extracted into the small volume of the surfactant-rich phase, thus yielding the desired preconcentration. The extraction yield depends on the $\mathrm{pH}$ at which complex formation occurs. The effect of different $\mathrm{pH}$ values on the $\mathrm{E} \%$ was recorded in the range of $\mathrm{pH} 2-11$ (Fig. 1) and the quantitative extraction was observed in the range of $\mathrm{pH} 5-7$. Therefore, $\mathrm{pH} 6$ was selected in future work.

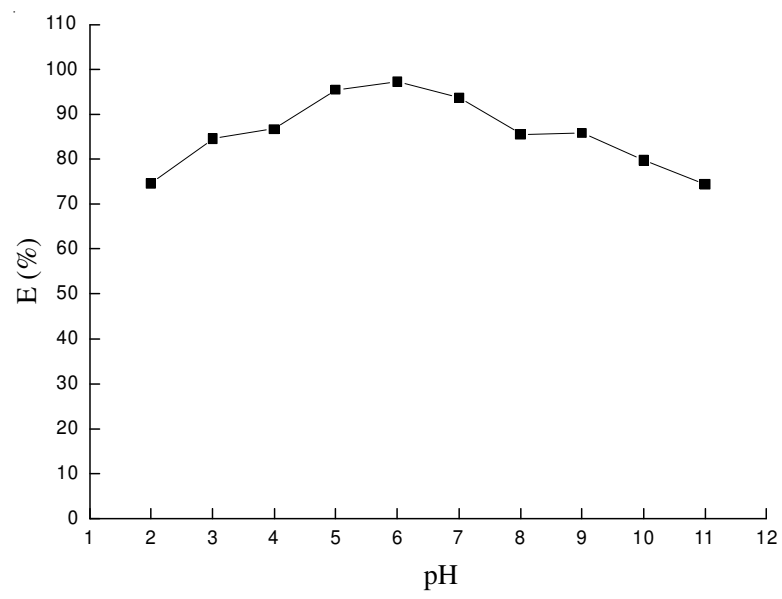

Fig. 1. Effect of $\mathrm{pH}$ on extraction

Effect of concentration of TritonX-100: Triton X-100 was chosen for the formation of the surfactant-rich phase due to its low cloud point temperature and high density of the surfactant-rich phase by which phase separation will be facilitated by centrifugation. Extraction of Pd(II) with the TritonX-100 concentration was investigated within the range of $0.2-4 \mathrm{~g} \mathrm{~L}^{-1}$, which is shown in Fig. 2. The optimum surfactant concentration used for the $\mathrm{Pd}(\mathrm{II})$ was $2 \mathrm{~g} \mathrm{~L}^{-1}$. So, the concentration of TritonX-100 was chosen as $2 \mathrm{~g} \mathrm{~L}^{-1}$ in order to achieve the optimal surfactant concentration in conjunction with the highest possible extraction efficiency.

Effect of the concentration of KI: The effect of KI concentration was investigated in the range of $2 \times 10^{-6}-0.04$ mol L${ }^{-1}$. The result was shown in Fig. 3. As Fig. 3 shows the
$\mathrm{E} \%$ for palladium in the surfactant-rich phase increased by increasing iodide concentration up to $0.005 \mathrm{~mol} \mathrm{~L}^{-1}$ and remained constant at higher concentrations. By increasing iodide concentration the concentration of $\left[\mathrm{PdI}_{4}\right]^{2-}$ of palladium increases and causes more extraction efficiency. So a $0.02 \mathrm{~mol}$ $\mathrm{L}^{-1} \mathrm{KI}$ concentration was used as optimal.

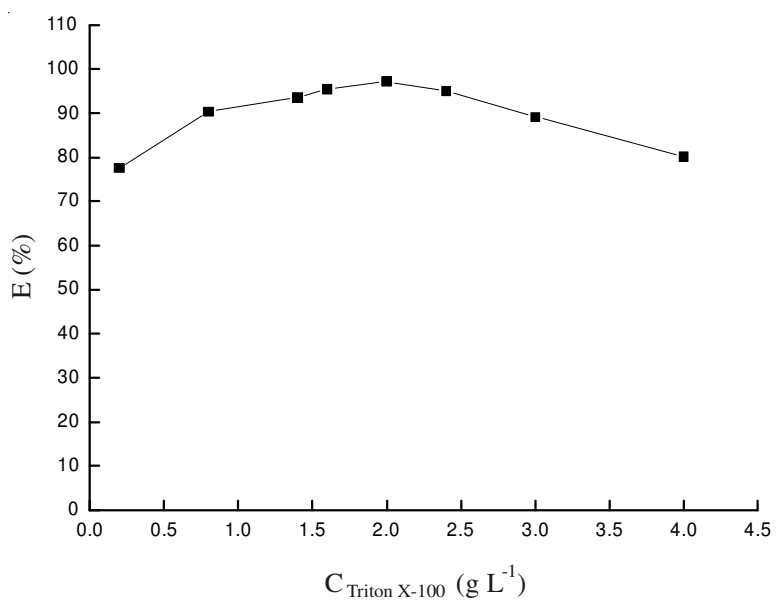

Fig. 2. Effect of Triton X-100

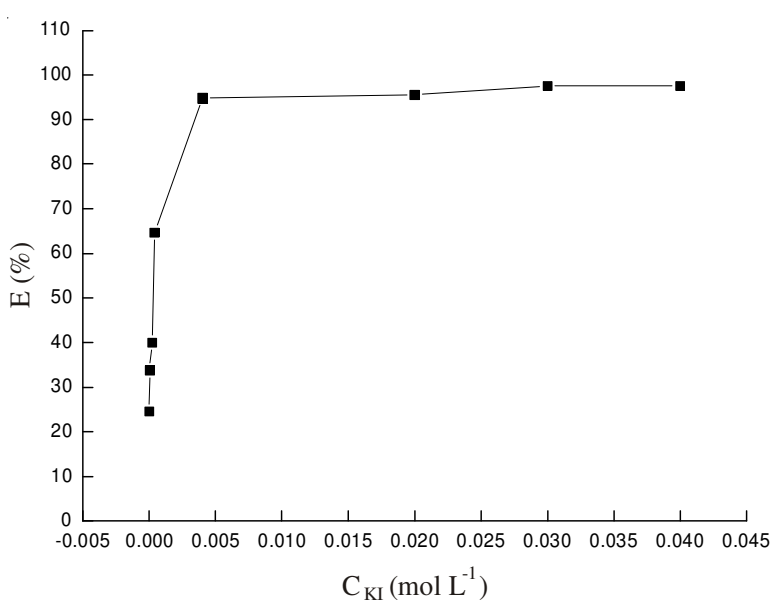

Fig. 3. Effect of KI

Effect of the equilibrium temperature and time: Optimal equilibration temperature and shortest time are necessary to complete reactions and to achieve easy phase separation and preconcentration as efficiently as possible. The results indicate that the experiment in the optimized reagent concentration after heating for $20 \mathrm{~min}$ in $50{ }^{\circ} \mathrm{C}$ and centrifuging by $10 \mathrm{~min}$ at $4000 \mathrm{rpm}$ and cooling to room temperature lead to high recovery in short time.

Characteristics of the method: Under the optimum conditions, the calibration graph was linear in the range 0.1 $60 \mu \mathrm{g} \mathrm{mL}^{-1}$. The calibration equation is $\mathrm{A}=0.00391 \mathrm{c}\left(\mu \mathrm{g} \mathrm{mL}^{-1}\right)$ +0.017 , with a correlation coefficient of 0.9962 . The limit of detection, defined as $\mathrm{DL}=3 \mathrm{SB} / \mathrm{m}$, where $\mathrm{SB}$ and $\mathrm{m}$ are standard deviation of the blank and the slope of the calibration graph, respectively, was $0.086 \mu \mathrm{g} \mathrm{mL}^{-1}$. The relative standard deviation was $1.8 \%\left(\mathrm{c}=5.0 \mu \mathrm{g} \mathrm{mL}^{-1}, \mathrm{n}=3\right)$.

Effect of coexisting ions: The effect of foreign ions on the preconcentration of palladium by the proposed method was investigated. An ion was considered as interfering when 
it caused a variation in the absorbance of the sample greater than $\pm 5 \%$. Tolerance limits (ion/Pd(II) (w/w)) of interfering ions in the determination of $5 \mathrm{ppm} \mathrm{Pd}(\mathrm{II})$ were list in the following: $\mathrm{Ca}^{2+}, \mathrm{K}^{+}, \mathrm{Na}^{+}, \mathrm{Zn}^{2+}, \mathrm{Cd}^{2+}(1000) ; \mathrm{Cr}^{3+}, \mathrm{Co}^{2+}, \mathrm{Ni}^{2+}$ (400); $\mathrm{Al}^{3+}$ (200); $\mathrm{Fe}^{3+}, \mathrm{Cu}^{2+}$ (32); $\mathrm{Pt}(\mathrm{IV}), \mathrm{Au}(\mathrm{III}), \mathrm{Ir}(\mathrm{IV})(5)$.

Determination of Palladium in different samples: In order to validate the method for accuracy, palladium in a certified reference material (GSB 04-1743-2004, certified value: $1000.00 \pm 3.4 \mathrm{ppm}$ ) was determined, the result was $9884 \pm 2.8 \mathrm{ppm}$ and the recovery was $98.8 \%$. There is no significant difference between the found value and the certified value for palladium. The proposed method was applied to determination of trace amounts of palladium in synthetic samples and the palladium catalyst waste water with satisfactory results (Tabel-1).

\begin{tabular}{|c|c|c|c|c|c|}
\hline \multicolumn{6}{|c|}{$\begin{array}{c}\text { TABLE-1 } \\
\text { DETERMINATION OF Pd(II) IN SYNTHETIC SAMPLE AND } \\
\text { PALLADIUM CATALYST WASTE WATER }(\mathrm{n}=3)\end{array}$} \\
\hline Sample & $\begin{array}{l}\text { Determinated } \\
\left(\mu \mathrm{g} \mathrm{mL}^{-1}\right)\end{array}$ & $\begin{array}{c}\text { Added } \\
\left(\mu \mathrm{g} \mathrm{mL}^{-1}\right)\end{array}$ & $\begin{array}{c}\text { Found } \\
\left(\mu \mathrm{g} \mathrm{mL}^{-1}\right)\end{array}$ & $\begin{array}{l}\text { RSD } \\
(\%)\end{array}$ & $\begin{array}{c}\text { Recovery } \\
(\%)\end{array}$ \\
\hline $\begin{array}{l}\text { Synthetic } \\
\text { sample }^{\mathrm{a}}\end{array}$ & 10.00 & $\begin{array}{c}4.00 \\
8.00 \\
12.00 \\
\end{array}$ & $\begin{array}{c}4.02 \\
7.92 \\
11.86 \\
\end{array}$ & $\begin{array}{l}1.24 \\
0.49 \\
0.82 \\
\end{array}$ & $\begin{array}{c}100.5 \\
99.0 \\
98.8 \\
\end{array}$ \\
\hline $\begin{array}{l}\text { Palladium } \\
\text { catalyst } \\
\text { waste water }\end{array}$ & 46.25 & $\begin{array}{c}4.00 \\
8.00 \\
12.00\end{array}$ & $\begin{array}{c}3.89 \\
7.89 \\
11.84\end{array}$ & $\begin{array}{l}1.03 \\
1.21 \\
1.08\end{array}$ & $\begin{array}{l}97.3 \\
98.6 \\
98.7\end{array}$ \\
\hline
\end{tabular}

\section{Conclusion}

A simple, rapid and sensitive cloud point extraction methodology has been developed and optimized for the preconcentration of trace palladium before its determination by flame atomic absorption spectrometry. The proposed procedure does not need any organic chelating agent, long incubation time. The proposed method can be applied to the preconcentration and determination of palladium in waste water sample.

\section{ACKNOWLEDGEMENTS}

The authors acknowledged the financial support from the Foundation of College Student Innovation Training Program of the Jiangsu Province in 2011, the Subject Foundation of Huaihai Institute of Techology (No. Z2011020) and the Foundation of Jiangsu Provincial Research Institute of Marine Resources in 2011 (JSIMR11B26).

\section{REFERENCES}

1. S. Daniel, J.M. Gladis and T.P. Rao, Anal. Chim. Acta, 488, 173 (2003).

2. R. Merget and G. Rosner, Sci. Total Environ., 270, 165 (2001).

3. P. Kovacheva and R. Djingova, Anal. Chim. Acta, 7, 464 (2002).

4. Y. Wu, B. Hu, Z. Jiang and Sh. Chen, J. Anal. At. Spectrom., 17, 121 (2002).

5. K. Benkhedda, B. Dimitrova, H.G. Infante, E. Ivanova and F.C. Adoms, J. Anal. At. Spectrom., 18, 1019 (2003).

6. M. Moldovan, M.M. G'omez and M.A. Palacios, Anal. Chim. Acta, 478, 209 (2003).

7. K. Boch, M. Schuster, G. Risse and M. Schwarzer, Anal. Chim. Acta, 459, 257 (2002).

8. P. Anderson, C.M. Davidson, D. Littlejohn, M.A. Ure, C.A. Shand and M.V. Cheshire, Anal. Chim. Acta, 327, 53 (1996).

9. B. Godelewska-Zylkiewicz, Microchim. Acta, 147, 189 (2004).

10. L. Bencs, K. Ravindra and R.V. Grieken, Spectrochim. Acta B, 58, 1723 (2003).

11. P. Liang, E. Zhao and F. Li, Talanta, 77, 1854 (2009).

12. M. Chappuya, E. Caudrona and A. Bellanger, J. Hazard. Mater., 176, 207 (2010).

13. K. Farhadi and G. Teimouri, Talanta, 65, 925 (2005).

14. F.S. Rojas, C.B. Ojeda and J.M.C. Pavon, Talanta, 70, 979 (2006). 